\title{
Hubungan Kualitas Hidup dan Kebutuhan Perawatan Paliatif Pasien Kanker Ginekologi di Rumah Sakit Dr. Hasan Sadikin
}

\author{
Rizna Tyrani Rumanti, Akhmad Yogi Pramatirta, Ali Budi Harsono, \\ Jusuf Sulaeman Effendi \\ Departemen Obstetri dan Ginekologi Fakultas Kedokteran Universitas Padjadjaran/ \\ RSUP Dr. Hasan Sadikin Bandung \\ Korespondensi: Rizna Tyrani Rumanti, riznatyrani@thewomens.org.au
}

\begin{abstract}
Abstrak
Tujuan. Tujuan penelitian ini adalah untuk mengetahui bagaimana hubungan kualitas hidup dan kebutuhan perawatan paliatif pada pasien kanker ginekologi.

Metode. Subjek penelitian ini adalah seluruh pasien kanker ginekologi yang dirawat di Rumah Sakit Dr. Hasan Sadikin Bandung pada bulan November-Desember 2018. Penelitian ini merupakan studi analitik dengan rancangan cross sectional. Data yang diperoleh dianalisis secara bivariat dengan menggunakan chi square dengan $\alpha=0,05$, untuk mengetahui hubungan antara kualitas hidup dengan kebutuhan perawatan paliatif.

Hasil. Karakteristik subjek terbanyak berusia $>50$ tahun $(65,67 \%)$, pendidikan dasar $(70,15 \%)$, ibu rumah tangga (89,55\%), pendapatan di atas upah minimum regional (61,19\%), tujuan rawat inap kemoterapi $(47,76 \%)$ dan tipe kanker karsinoma serviks (43,28\%). Subjek penelitian dengan skor paliatif $\geq 4$ sebanyak 25 orang $(37,31 \%)$. Keluhan yang terbanyak adalah berat badan turun dan tidak nafsu makan $(86,57 \%)$. Kualitas hidup pasien kategori baik sebanyak 29 orang, sedang 36 orang, dan kurang 2 orang. Kualitas hidup pasien kanker ginekologi berhubungan dengan kebutuhan perawatan paliatif dengan nilai signifikansi p 0,004.

Simpulan. Kualitas hidup berhubungan dengan skor paliatif. Semakin rendah skor paliatif maka kualitas hidup semakin baik.
\end{abstract}

Kata Kunci: Kanker ginekologi; kualitas hidup; skor paliatif

\section{Relations of Quality of Life and Characteristics of Gynecological Cancer Patients In Hasan Sadikin Hospital}

\begin{abstract}
Aim: The purpose of this study was to determine the characteristics of gynecological cancer patients, determine the quality of life of all gynecological cancer patients and to asses the correlation of quality of life and palliative care needs in gynecological cancer patients.

Method: The subjects of this study were all gynecological cancer patients who were treated at Dr. Hasan Sadikin Hospital Bandung in November-December 2018. This study was an analytic study with a cross sectional design. Data obtained from the study were analyzed bivariately using chi square with $\alpha=0.05$, to determine the relationship between quality of life and palliative care needs.

Results: The most characteristics of the subjects were with age $>50$ years (65.67\%), primary education (70.15\%), housewives (89.55\%) with income above the regional minimum wage (61.19\%), the main goal of hospitalization is chemotherapy (47.76\%) and the most types of cancer are cervical carcinoma (43.28\%). The research subjects who had a palliative score of $\geq 4$ were 25 people (37.31\%). The most complaints were weight loss and no appetite (86.57\%). The quality of life of patients with good category was 29 people, medium category was 36 people and poor category was 2 people. The quality of life of gynecological cancer patients has correlation with palliative care needs with a significance value of $p 0.004$.

Conclusion: Quality of life has correlation with palliative scores, the lower the palliative score, the better the quality of life.
\end{abstract}

Keywords: Gynecological cancer; quality of life; palliative score 


\section{Pendahuluan}

\section{World Health Organization (WHO)} mendefinisikan perawatan paliatif sebagai pendekatan untuk meningkatkan kualitas hidup pasien dan keluarga mereka yang menghadapi penyakit yang mengancam jiwa, melalui pencegahan dan pemulihan penderitaan dengan cara identifikasi dini dan penilaian yang sempurna serta pengobatan nyeri dan masalah lainnya, fisik, psikososial, dan spiritual. ${ }^{1}$

Sekitar 1.085.948 wanita di dunia telah didiagnosis dengan kanker ginekologi, dan sekitar setengah dari wanita ini meninggal karena kanker. Sejumlah besar pasien dengan kanker ginekologi menderita sejumlah gejala yang secara fisik berat (seperti rasa sakit) serta beban psikososial dan spiritual. Prosedur diagnosis dan pengobatan yang diterapkan untuk kanker ginekologi secara negatif mempengaruhi kualitas hidup pasien dan keluarga dalam hal citra tubuh, identitas seksual, dan kemampuan reproduksi, di samping masalah yang dialami pada kanker di organ lain. Perawatan yang diberikan selama proses penyakit mungkin tetap tidak efektif, dan penyakit dapat berkembang atau kambuh. Dalam studi prospektif pada 240 pasien dengan kanker, pasien mengalami rata-rata 13 (kisaran 2-30) gejala selama diagnosis dan proses pengobatan. Penelitian retrospektif oleh Jung et al. mendapatkan gejala yang dialami oleh pasien dengan kanker ginekologi adalah $82 \%$ pasien mengalami nyeri, $72 \%$ anoreksia, 69\% kelelahan dan 54\% masalah insomnia. Gejala dapat mengganggu kualitas hidup wanita dan keluarga mereka dan menyebabkan kepatuhani pengobatan sulit. ${ }^{2}$

Perawatan paliatif terutama bertujuan untuk meningkatkan kualitas hidup pasien dan keluarga mereka. Perawatan paliatif saat ini secara keliru telah berubah menjadiperawatan akhir-hidup. Ada tiga kategori penyakit utama yang mungkin memerlukan perawatan paliatif: kanker, penyakit progresif non- ganas dan penyakit terminal anak-anak. Oleh karena itu, para penderita kanker ginekologi mungkin membutuhkan perawatan paliatif lebih dari yang diperkirakan sebelumnya. Untuk memperkirakan kebutuhan perawatan paliatif, dua strategi dapat diadopsi: pertama, dengan pendekatan epidemiologi, yang meneliti kematian pada penyakit yang mungkin bermanfaat dari perawatan paliatif, berkaitan dengan jenis dan frekuensi gejala yang dialami pasien; dan kedua, dengan mengevaluasi penggunaan layanan kesehatan dan bukti dari pasien dan keluarga yang menerima perawatan. ${ }^{3,4}$ however, palliative care has broadened its focus from terminal cancer patients to patients with other serious, life-limiting illnesses. Nevertheless, the identification of palliative care needs $\left(\mathrm{PCNs}^{5}{ }^{5}\right.$

Integrasi perawatan paliatif, baik dalam kombinasi dengan perawatan standar atau sebagai fokus utama perawatan, menghasilkan kualitas hidup pasien yang lebih baik dan mengurangi penggunaan perawatan intensif yang sia-sia. Fokus pada perawatan paliatif dan menghilangkan gejala selama perjalanan penyakit harus menjadi yang utama untuk mendapatkan kualitas hidup pasien yang lebih baik. Oleh karena itu, penentuan kebutuhan perawatan paliatif harus memperhatikan setiap gejala yang dialami pasien agar kualitas hidup setiap pasien kanker ginekologi menjadi lebih baik. ${ }^{3}$ however, palliative care has broadened its focus from terminal cancer patients to patients with other serious, life-limiting illnesses. Nevertheless, the identification of palliative care needs (PCNs

Rumah Sakit Dr. Hasan Sadikin (RSHS) Bandung merupakan rumah sakit kelas A yang menjadi rujukan tertinggi (Top referral Hospital) di Provinsi Jawa Barat, juga menjadi Rumah Sakit Rujukan Nasional dan Rumah Sakit Pendidikan yang bermutu dan berdaya saing di tahun 2019. Salah satu unggulan Rumah Sakit Dr. Hasan Sadikin salah satunya adalah menjadi pusat unggulan nasional 
dalam Bidang Ginekologi Onkologi. Bidang Ginekologi Onkologi ini melayani seluruh pasien kanker ginekologi, seperti operasi, kemoterapi, radiasi hingga perawatan paliatif. Setiap pasien kanker ginekologi yang dirawat di Rumah Sakit Dr. Hasan Sadikin dilakukan penapisan perawatan paliatif menggunakan suatu form scoring khusus dari Tim Paliatif Rumah Sakit Dr. Hasan Sadikin. Pasien dengan score paliatif $>4$ akan mendapatkan perawatan paliatif oleh Tim Paliatif Rumah Sakit Dr. Hasan Sadikin. ${ }^{6}$

Berdasarkan uraian di atas penulis ingin mengetahui bagaimana karakteristik dan kualitas hidup pasien kanker ginekologi serta hubungan kualitas hidup dengan kebutuhan perawatan paliatif pada seluruh pasien kanker ginekologi yang dirawat di Rumah Sakit Dr. Hasan Sadikin.

\section{Metode}

Subjek penelitian adalah semua kasus wanita dengan kanker ginekologi yang dirawat di Ruang Alamanda B Rumah Sakit Dr. Hasan Sadikin periode November-Desember 2018.

Kriteria Inklusi:

1. Wanita yang dirawat di Ruang Alamanda B Rumah Sakit Dr. Hasan Sadikin periode November-Desember 2018

2. Pasien telah didiagnostik kanker ginekologi secara Patologi Anatomi

3. Bersedia menjadi responden penelitian dengan mengisi lembar informed consent

Kriteria Eksklusi: Pasien dengan penurunan kesadaran

Penelitian ini merupakan penelitian deskriptif analitik dengan desain penelitian cross sectional. Subjek penelitian adalah pasien kanker ginekologi yang dirawat di Rumah Sakit Dr. Hasan Sadikin.
Data penelitian didapatkan dari wawancara, kuesioner, dan rekam medis pasien dengan kegananasan yang dirawat di Ruang Alamanda B Rumah Sakit Dr. Hasan Sadikin periode November 2018.

Penilaian kualitas hidup menggunakan alat bantu kuesioner Functional Assessment Cancer of Therapy-General (FACT-G versi 4). FACT-G Versi 4 memiliki 27 pertanyaan, yang masing-masing dijawab menggunakan skala 5 poin mulai dari 0 (Tidak sama sekali) hingga 4 (Sangat banyak). Pertanyaan dari kondisi kesehatan responden selama 7 hari terakhir dalam empat subskala: kesejahteraan fisik (7 pertanyaan), sosial/kesejahteraan keluarga (7 pertanyaan), kesejahteraan emosional (6 pertanyaan), dan kesejahteraan fungsional (7 pertanyaan). Semakin tinggi skor semakin baik kualitas hidup pasien. Kuesioner ini telah divalidasi dan digunakan di berbagai negara serta telah diterjemahkan dalam berbagai Bahasa. Setiap pasien kanker ginekologi yang dirawat di Rumah Sakit Dr. Hasan Sadikin dilakukan penapisan perawatan paliatif. Pasien dengan score paliatif $>4$ akan mendapatkan perawatan paliatif oleh Tim Paliatif Rumah Sakit Dr. Hasan Sadikin. Data yang diperoleh dari penelitian dianalisis secara bivariat dengan menggunakan chi square dengan $\alpha=0,05$, untuk mengetahui hubungan antara kualitas hidup dengan kebutuhan perawatan paliatif.

\section{Hasil}

Penelitian terhadap pasien wanita dengan kanker ginekologi yang dirawat di Ruang Alamanda B Rumah Sakit Dr. Hasan Sadikin periode November-Desember 2018 dengan jumlah sampel 67 orang. Karakteristik dari subjek penelitian ditunjukkan pada Tabel 1.

Subjek penelitian telah dilakukan penggalian keluhan yang dialami saat dirawat di Ruang Alamanda B Rumah Sakit Dr. Hasan Sadikin periode November-Desember 2018.

Tabel 2 menunjukkan seluruh keluhan 
yang dialami oleh pasien. Berdasar Tabel 2, keluhan subjek penelitian yang terbanyak adalah berat badan turun dan tidak nafsu makan $(86,57 \%)$ diikuti keluhan nyeri $(77,61 \%)$.

\section{Tabel 1 Karakteristik Subjek Penelitian}

\begin{tabular}{lll}
\hline \multicolumn{1}{c}{ Karakteristik } & Jumlah & Persen \\
\hline Usia & & \\
$>50$ tahun & 44 & 65,67 \\
$\leq 50$ tahun & 23 & 34,43 \\
Pendidikan & & \\
Dasar (SD, SMP) & 47 & 70,15 \\
Lanjut (SMA, & 20 & 29,85 \\
Universitas) & & \\
Pekerjaan & & \\
IRT & 60 & 89,55 \\
Karyawan & 7 & 10,45 \\
Pendapatan & & \\
$>$ UMR & 41 & 61,19 \\
$\leq$ UMR & 26 & 38,80 \\
Tujuan Rawat & & \\
Inap & & \\
Operasi & 13 & 19,40 \\
Kemoterapi & 32 & 47,76 \\
Perbaikan Keadaan & 22 & 32,84 \\
Umum & & \\
Tipe kanker & & 37,31 \\
Ovarium & 24 & 5,89 \\
Endometrium & 4 & 43,28 \\
Serviks & 29 & 14,92 \\
Trofoblas & 10 & \\
Skor paliatif & & \\
$<4$ & 42 & \\
< 4 & 25 & \\
\hline
\end{tabular}

Tabel 2 Keluhan Subjek Penelitian

\begin{tabular}{lcc}
\hline \multicolumn{1}{c}{ Keluhan } & Jumlah & Persen \\
\hline Kurang bertenaga & 51 & 76,11 \\
Mual & 42 & 62,68 \\
Nyeri & 52 & 77,61 \\
Bengkak pada perut & 15 & 22,38 \\
Berat badan turun & 58 & 86,57 \\
Gangguan defekasi & 11 & 16,42 \\
Muntah & 29 & 43,28 \\
Rambut rontok & 38 & 56,72 \\
Tidak nafsu makan & 58 & 86,57 \\
Kram daerah perut & 8 & 11,94 \\
Perdarahan & 12 & 17,91 \\
dari jalan lahir & 8 & 11,94 \\
Keputihan & 33 & 49,25 \\
Sulit tidur & 15 & 22,38 \\
Gangguan miksi & 22 & 32,83 \\
Benjolan di perut & & \\
\hline
\end{tabular}

Kualitas hidup subjek penelitian dapat dilihat pada Tabel 3. Kualitas hidup pasien kategori baik sebanyak 28 orang $(41,79 \%)$, sedang 37 orang $(55,22 \%)$ dan kurang dari 2 orang $(2,99 \%)$. Penilaian kualitas hidup menggunakan alat bantu kuesioner Functional Assessment Cancer of TherapyGeneral (FACT-G versi 4).

Tabel 3 Kualitas Hidup Subjek Penelitian

\begin{tabular}{ccc}
\hline $\begin{array}{c}\text { Kualitas } \\
\text { Hidup } \\
\text { Baik }\end{array}$ & $\begin{array}{c}\text { Kualitas } \\
\text { Hidup } \\
\text { Sedang }\end{array}$ & $\begin{array}{c}\text { Kualitas } \\
\text { hidup } \\
\text { Kurang }\end{array}$ \\
\hline $29(43,28 \%)$ & $36(53,37 \%)$ & $2(2,99 \%)$ \\
\hline
\end{tabular}

Tabel 4 Kualitas Hidup Subjek Penlitian

\begin{tabular}{lcccc}
\hline $\begin{array}{c}\text { No/Skor } \\
\text { Paliatif }\end{array}$ & $\begin{array}{c}\text { Kualitas Hidup } \\
\text { Baik }\end{array}$ & $\begin{array}{c}\text { Kualitas Hidup } \\
\text { Sedang }\end{array}$ & $\begin{array}{c}\text { Kualitas hidup } \\
\text { Kurang }\end{array}$ & P value \\
\hline$<\mathbf{4}$ & 24 & 18 & 0 & 0,04 \\
$\geq \mathbf{4}$ & 5 & 18 & 2 & \\
Jumlah & $29(43,28 \%)$ & $36(53,37 \%)$ & $2(2,99 \%)$ & \\
\hline
\end{tabular}


Tabel 4 menunjukkan bahwa pada pasien dengan skor paliatif $<4$, yang memiliki kualitas hidup baik sebanyak 24 orang, kualitas hidup sedang 18 orang dan tidak ada yang memiliki kualitas hidup kurang. Pasien dengan skor paliatif $\geq 4$ yang memiliki kualitas hidup baik sebanyak 5 orang, kualitas hidup sedang 18 orang dan tidak ada yang memiliki kualitas hidup kurang 2 orang.

Hubungan kualitas hidup dan kebutuhan perawatan paliatif diuji menggunakan uji chi square dan didapatkan nilai signifikansi $\mathrm{p}=0,004 \quad(<0,0,5)$. Hal ini menunjukkan bahwa kualitas hidup berhubungan secara signifikan dengan skor paliatif. Sehingga semakin rendah skor paliatif maka kualitas hidup semakin baik.

\section{Pembahasan}

Subjek penelitian ini sebagian besar berusia $>50$ tahun $(65,67 \%)$. Hal ini sesuai dengan studi yang dilakukan oleh White, dkk. bahwa usia digunakan dalam hampir semua studi epidemiologi kanker dan merupakan salah satu faktor risiko kanker yang paling banyak dipelajari. Kanker dapat dianggap sebagai penyakit yang berkaitan dengan usia karena kejadian sebagian besar kanker meningkat dengan bertambahnya usia, walaupun faktor risiko ini mungkin akan berbeda berdasar jenis kanker. ${ }^{11}$

Macdonalds, dkk. mendapatkan bahwa bertambahnya usia adalah faktor risiko untuk terserang kanker. Di Inggris tiga perempat kasus kanker didiagnosis pada usia di atas 60 tahun, dan sepertiga didiagnosis pada usia di atas 75 tahun. Orang dewasa yang lebih tua mengalami luaran kanker yang lebih buruk, memiliki kesadaran risiko dan gejala yang lebih rendah, dan lebih cenderung mengalami diagnosis stadium lanjut. Oleh karena itu, penting bagi orang dewasa yang lebih tua menghargai risiko tinggi mereka, khususnya dalam konteks keputusan mencari bantuan. ${ }^{12}$ Sebanyak 47 orang $(70,15 \%$
) dari seluruh subjek penelitian memiliki tingkat pendidikan dasar (SD/SMP). Hal ini sesuai dengan studi yang dilakukan oleh Leuven, dkk. bahwa tingkat pendidikan yang lebih tinggi sebanding dengan pengurangan risiko kanker secara keseluruhan, baik untuk pria maupun wanita. Tingkat pendidikan yang lebih tinggi serta individu dengan masa sekolah yang lebih lama menunjukkan risiko metastasis dan risiko kematian kanker yang lebih kecil. ${ }^{13}$

Mouw, dkk. menyatakan bahwa status sosial ekonomi rendah telah dikaitkan dengan peningkatan risiko kanker. Pendidikan sebagai salah satu indikator status sosial ekonomi, telah terbukti berbanding terbalik dengan kejadian kanker di beberapa (tetapi tidak semua) lokasi anatomi. Dengan demikian semakin tinggi tingkat pencapaian pendidikan, semakin rendah risiko kanker. ${ }^{14}$

Sebagian besar subjek penelitian adalah ibu rumah tangga atau tidak terikat pekerjaan. Pengobatan kanker ginekologi membutuhkan waktu yang cukup lama, bahkan pasien dapat beberapa kali dirawat di rumah sakit, baik untuk kemoterapi, radiasi, operasi maupun untuk perbaikan keadaan umum. Hal ini menjadi salah satu faktor seorang penderita kanker ginekologi sulit untuk terikat dengan pekerjaan. Hasil penelitian ini sesuai dengan hasil penelitian Dias, dkk. bahwa penderita kanker yang bekerja akan sering mengambil cuti atau beralih ke jadwal kerja yang fleksibel selama atau setelah perawatan kanker dan pada akhirnya dapat menjadi pengangguran. ${ }^{15}$

Sebagian besar subjek penelitian memiliki pendapatan di atas upah minimum regional. Pasien yang dirawat di Rumah Sakit dr. Hasan Sadikin sebagian besar adalah pasien rujukan dari rumah sakit daerah di luar Bandung. Walaupun pengobatan kanker sebagian besar ditanggung Badan Penyelenggara Jaminan Sosial kesehatan namun keluarga pasien tetap harus mengeluarkan untuk transportasi dan akomodasi keluarga, sehingga sebagian besar 
yang dirawat adalah pasien dengan dukungan finansial yang cukup besar dari keluarga.

Aggarwal, dkk. menemukan bahwa pasien kanker yang mencari pengobatan adalah mereka yang secara pendapatan menengah ke atas, sumber dana didapatkan dari diri sendiri, keluarga maupun asuransi pemerintahan. Pasien dengan pendapatan rendah cenderung kurang mencari pengobatan karena keterbatasan dana. ${ }^{16}$

Tujuan rawat inap terbanyak adalah untuk kemoterapi, yaitu sebanyak 32 orang $(47,76 \%)$. Masa rawat inap kemoterapi relatif singkat, mulai dari $2-8$ hari, dan berulang setiap 1/2/3 minggu, sehingga pasien yang dirawat untuk kemoterapi relatif lebih banyak dibanding dengan pasien yang dirawat untuk operasi maupun perbaikan keadaan umum. Hasil penelitian ini tidak sesuai dengan penelitian Numico, dkk., bahwa pada 149 pasien onkologi yang dirawat pada tahun $201066 \%$ kasus pasien dirawat karena gejala dan hanya 3\% untuk administrasi kemoterapi. ${ }^{17}$ and the outcome of the hospital stay. RESULTS 672 admissions of 454 patients were analysed. The majority of admissions were urgent $(74,1 \%)$

Jenis/tipe kanker terbanyak dari subjek penelitian adalah kanker serviks, yaitu 29 orang $(43,28 \%)$. Hal ini sesuai dengan data Riset Kesehatan Dasar 2013 bahwa prevalensi kanker ginekologi terbanyak di Indonesia adalah kanker serviks, yaitu $0,08 \%{ }^{18}$ Di dunia kanker serviks juga menempati urutan pertama sebagai penyebab kanker ginekologi terbanyak. ${ }^{19}$

Keluhan subjek penelitian yang terbanyak adalah berat badan turun dan tidak nafsu makan $(86,57 \%)$. Tidak nafsu makan adalah gejala umum dan signifikan pada kanker ginekologi dengan banyak penyebab dan konsekuensi gizi yang serius, yaitu penurunan berat badan. Pasien dengan kanker menunjukkan penurunan berat badan secara progresif, terutama disebabkan oleh hilangnya lemak dan otot rangka. Kehilangan jaringan adiposa terjadi terutama karena peningkatan lipolisis. Lipolisis diinduksi oleh produk tumor, Faktor Mobilisasi Lipid (LMF), yang bertindak melalui adrenoseptor $\beta 3$. Hilangnya otot rangka muncul dari penurunan sintesis protein dan peningkatan degradasi protein. Penurunan sintesis protein dapat timbul dari ketidakaktifan pasien, ditambah dengan pengurangan pasokan atau keseimbangan asam amino karena produksi protein fase akut. Peningkatan degradasi protein terutama disebabkan oleh peningkatan ekspresi komponen jalur proteolitik pada otot rangka. Katabolisme sel sebagian dimediasi oleh sitokin seperti faktor nekrosis tumor $\alpha$ (TNF- $\alpha$ ) atau interleukin ( IL)-1 dan IL-6. Produk katabolik tumor seperti LMF dan proteolysis-inducing factor (PIF) secara langsung merangsang kerusakan jaringan, dan juga berkorelasi dengan penurunan berat badan pada pasien kanker. ${ }^{20}$ Kualitas hidup subjek penelitian kategori baik sebanyak 29 orang, sedang 36 orang dan kurang 2 orang. Hubungan kualitas hidup dan kebutuhan perawatan paliatif diuji menggunakan chi square dan didapatkan nilai signifikansi $\mathrm{p}=0,004(<0,05)$.

Hal menunjukkan bahwa kualitas hidup berhubungan secara signifikan dengan skor paliatif. Sehingga semakin rendah skor paliatif maka kualitas hidup semakin baik, atau semakin baik kualitas hidup pasien maka kebutuhan perawatan paliatif semakin rendah.

Subjek penelitian dengan kualitas hidup kurang semua memiliki skor paliatif $>4$. Jadi, terdapat kesesuaian bahwa pasien dengan kualitas hidup kurang membutuhkan perawatan paliatif yang ditunjukkan dengan nilai skor paliatif $\geq 4$.

Pada pasien dengan kualitas hidup sedang sebanyak 19 orang dari 25 ternyata memiliki skor paliatif $<4$. Skor paliatif ini hanya menilai keadaan fisik pasien, sedangkan kualitas hidup menilai kesejahteraan fisik, sosial/kesejahteraan keluarga, kesejahteraan 
emosional, dan kesejahteraan fungsional. Artinya pasien ini secara fisik mungkin tidak membutuhkan dukungan paliatif, tetapi secara sosial, emosional atau fungsional membutuhkan.

Sebaliknya, pada pasien dengan skor paliatif $\geq 4$ terdapat 5 orang yang memiliki kualitas hidup yang baik. Hal ini kemungkinan disebabkan besarnya dukungan keluarga dan motivasi pada pasien itu sendiri, sehingga tingkat kesejahteraan sosial, emosional atau fungsional tinggi, walaupun tingkat kesejahteraan fisik rendah. Simpulan yang dapat ditarik dari penelitian ini adalah karakteristik pasien kanker ginekologi yang dirawat di Rumah Sakit Dr. Hasan Sadikin pada bulan November-Desember 2018 yang terbanyak berusia $>50$ tahun $(65,67 \%)$, pendidikan dasar $(70,15 \%)$, ibu rumah tangga $(89,55 \%)$ dengan pendapatan di atas upah minimum regional $(61,19 \%)$, tujuan rawat inap terbanyak adalah kemoterapi $(47,76 \%)$ dan tipe kanker terbanyak adalah karsinoma serviks $(43,28 \%)$. Subjek penelitian yang memiliki skor paliatif $\geq 4$ sebanyak 25 orang $(37,31 \%)$. Keluhan yang terbanyak adalah berat badan turun dan tidak nafsu makan $(86,57 \%)$ diikuti keluhan nyeri $(77,61 \%)$.

Kualitas hidup pasien kanker ginekologi yang dirawat di Rumah Sakit Dr. Hasan Sadikin pada bulan November-Desember 2018 kategori baik sebanyak 29 orang $(53,73 \%)$, sedang 36 orang $(43,28 \%)$ dan kurang $2(2,99 \%)$ orang. Kualitas hidup pasien kanker ginekologi secara statistik signifikan berhubungan dengan kebutuhan perawatan paliatif $(\mathrm{p}<0,005)$.

\section{Daftar Pustaka}

1. Karlin D, Phung P, Pietras C. Palliative care in gynecologic oncology. Curr Opin Obstet Gynecol. 2017 Dec;30(1):31-43.

2. Terzioğlu F, Şahan FU. Palliative Care in Gynecologic Cancers. J Palliat Care Med. 2016;6(5):25-7.
3. Meffert C, Rücker G, Hatami I, Becker G. Identification of hospital patients in need of palliative care--a predictive score. BMC Palliat Care. 2016 Feb 22;15:21.

4. Franks PJ, Salisbury C, Bosanquet N, Wilkinson EK, Kite S, Naysmith A, et al. The level of need for palliative care: a systematic review of the literature. Palliat Med. 2000 Mar 1;14(2):93-104.

5. McIlfatrick S. Assessing palliative care needs: views of patients, informal carers and healthcare professionals. J Adv Nurs. 2007 Jan 1;57(1):77-86.

6. Aditiyono AA, Harsono AB, Susanto H. CA 125 Dan Risk Of Malignancy Index (RMI)2 Sebagai Prediktor Kegansan Tumor Ovarium Tipe Epitel. Mandala Heal A Sci J. 2018 Oct 17;11(1):18-30.

7. Casey C, Chen L, Rabow MW. Symptom management in gynecologic malignancies. Expert Rev Anticancer Ther. 2011 Jul 10;11(7):1079-91.

8. Johnsen AT, Petersen MA, Pedersen L, Groenvold M. Development and Initial Validation of the Three-Levels-of-Needs Questionnaire for Self-Assessment of Palliative Needs in Patients with Cancer. J Pain Symptom Manage. 2011 Jun 1;41(6):1025-39.

9. Ferris FD, Bruera E, Cherny N, Cummings C, Currow D, Dudgeon D, et al. Palliative Cancer Care a Decade Later: Accomplishments, the Need, Next Steps-From the American Society of Clinical Oncology. J Clin Oncol. 2008;27(18):3052-8.

10. Rosanne Moses, Philip JAM, Lickiss JN. Berek and Hacker's Gynecologic Oncology - Google Books. Berek JS, Hacker NF editors, editor. Lippincott Williams \& Wilkins; 2010. 902-25 p.

11. White MC, Holman DM, Boehm JE, Peipins LA, Grossman M, Henley SJ. Age and cancer risk: a potentially modifiable relationship. Am J Prev Med. 2014 Mar;46(3 Suppl 1):S7-15. 
12. Macdonald S, Cunningham Y, Patterson C, Robb K, Macleod U, Anker T, et al. Mass media and risk factors for cancer: the under-representation of age. BMC Public Health. 2018;18(1):490.

13. Leuven E, Plug E, Rønning M. Education and cancer risk. Labour Econ. 2016 Dec 1;43:106-21.

14. Mouw T, Koster A, Wright ME, Blank MM, Moore SC, Hollenbeck A, et al. Education and Risk of Cancer in a Large Cohort of Men and Women in the United States. von Elm E, editor. PLoS One. 2008 Nov 4;3(11):e3639.

15. Dias D, Leite Â, Ramires A, Bicho P. Working with cancer: motivation and job satisfaction. Int J Organ Anal. 2017 Sep 4;25(4):662-86.

16. Aggarwal A. The challenge of cancer in middle-income countries with an ageing population: Mexico as a case study. Ecancermedicalscience. 2015 May 7;9.

17. Numico G, Cristofano A, Mozzicafreddo A, Cursio OE, Franco P, Courthod G, et al. Hospital admission of cancer patients: avoidable practice or necessary care? PLoS One. 2015;10(3):e0120827.

18. Kementrian Kesehatan Indonesia. Pusat Data dan Informasi Kementrian Kesehatan Indonesia [Internet]. 2013 [cited 2019 Feb 25]. Available from: http://www.depkes.go.id/resources/ download/pusdatin/infodatin/infodatinkanker.pdf

19. Sankaranarayanan R, Head MD, Group S, Ferlay J. Worldwide burden of gynaecological cancer: The size of the problem.

20. Tisdale MJ. Cachexia in cancer patients. Nat Rev Cancer. 2002 Nov 1;2(11):862-71. 